\title{
Determinants of Audit Fees: Evidence from an Emerging Economy
}

\author{
Yousef Mohammad Hassan ${ }^{1} \&$ Kamal Naser ${ }^{2}$ \\ ${ }^{1}$ Department of Accounting, Finance and Banking, Al Ain University of Science and Technology, Al Ain, UAE \\ ${ }^{2}$ Kuwait Fund, Cardiff, UK \\ Correspondence: Kamal Naser, Kuwait Fund, 36 Amesbury Road, Penylan, Cardiff CF23 5DX, UK. E-mail: \\ profnaser@yahoo.co.uk
}

Received: June 13, 2013

Accepted: July 12, 2013

Online Published: July 25, 2013

doi:10.5539/ibr.v6n8p13

URL: http://dx.doi.org/10.5539/ibr.v6n8p13

\begin{abstract}
This study sets out to examine factors influencing audit fees paid by non-financial companies listed on Abu Dhabi Stock Exchange (ADX). Data were collected from the 2011 annual and corporate governance reports published by the Emirati non-financial companies listed on ADX. Backward regression analysis is employed to assess the association between audit fees and certain company's attributes. The findings show a direct relationship between audit fees and each of corporate size, business complexity and audit report lag variables. An inverse relationship has been detected between audit fees and each of industry type and audit committee independence. The findings also revealed that audit fees are not significantly influenced by company's profitability, risk, and status of audit firm.
\end{abstract}

Keywords: audit fees, emerging economy, UAE, Abu Dhabi Securities Exchange (ADX)

\section{Introduction (Note 1)}

External audit is an important factor in the corporate governance function. The responsibility of the external auditor is to assure users of corporate financial statements that the statements are true and fair. Consequently, external auditors are seen by the users of corporate financial statements as being independent, objective and unlikely to be influenced by their clients. The important role that an external auditor plays in corporate governance would be influenced by fees charged to clients. Consequently, several studies have been undertaken to identify variables influencing audit fees all over the world. The majority of these studies covered developed countries (e.g., Taylor \& Baker, 1981; Francis, 1984; Francis \& Stokes, 1986; Haskins \& Williams, 1988; Chan et al., 1993; Anderson \& Zeghal, 1994; Ezzamelet et al., 1996; Iyer \& Iyer, 1996; Craswell \& Francis, 1999; Ezzamel et al., 2002; Neimi, 2006; Simon \& Taylor, 2002; Gonthier \& Schatt, 2007; Wang et al., 2009). Yet, limited number of studies covered Arab and Middle Eastern countries (Joshi \& Al-Bastaki, 2000; Kutoband Al-Khater, 2004; Naser \& Nuseibeh, 2008). Hence, more research efforts are still needed in Arab and Middle Eastern countries. As far as the UAE is concerned, no attempt has been made to explore variables influencing audit fees paid by Emirati nonfinancial companies listed on ADX. Undertaking this type of studies requires disclosing audit fees. This was not available until the end of 2011 when Ministry of Economy issued Ministerial Resolution No. 518 of 2009 concerning Governance Rules and Corporate Discipline Standards and asked companies listed on ADX to disclose audit fees. This Resolution was an update to Decision No. R/32, concerning corporate governance rules and requirements, that should be followed by nonfinancial companies listed on ADX. Ministerial Resolution No. 518 became effective from 30 April 2010. Consequently, companies listed on ADX started to publish audit fees in 2011 annual reports. It is important to mention that the Resolution was applied to nonfinancial companies since financial companies (banks, insurance, investment, money exchange and brokers) are supervised by the Central Bank. Hence, identifying variables that impact audit fees paid by companies listed on ADX will be a pioneering study since the listed companies never disclosed audit fees before. The choice of nonfinancial companies was mainly due to the fact that all these companies must comply with Ministerial Resolution No. 518. In addition, all companies operating in the UAE are exempted from paying income tax. Furthermore, unlike other developed countries where few audit firms compete for many companies, a limited number of companies are listed on ADX and many international, regional and local audit firms are operating in the UAE. This would result in imbalance between the supply and demand for external audit. This is expected to influence audit fees paid by companies listed on ADX. Thus, the unique features of the Emirati nonfinancial companies listed on ADX and the UAE market would add a new dimension to the literature of the determinants 
of audit fees.

The remainder of this paper is organised as follows. Previous related studies concerning determinants of audit fees together with hypotheses development are offered in the following section. Study methodology is explained in section three. While the findings are discussed in the fourth section, the conclusion is presented in the last section.

\section{Previous Related Studies and Hypotheses Development}

Previous literature on the determinants of the audit fees has investigated the relationship between audit fees and various corporate attributes. The most common attributes employed in previous research include corporate size, profitability, risk, complexity, industry type, the status of audit firm, audit report lag and audit committee independence. Literature related to these attributes is reviewed below.

\subsection{Corporate Size}

Large size companies would be involved in more activities than small ones. They are usually more publicly visible and they tend to disclose more information than small companies. Consequently, more audit services and time are needed to audit large size companies than small ones. They also have enough financial resources to recruit big international audit firms. Hence, large size companies would pay higher fees than small ones (Palmrose, 1986; Carson et al., 2004; Vermeer et al., 2009). Previous empirical research showed size to be the main factor that influences external auditor's fees (Taylor \& Baker, 1981; Francis, 1984; Firth, 1985; Simon, et al., 1986; Simon et al., 1992; Chan et al., 1993; Anderson \& Zeghal, 1994; Johnson et al., 1995; Collier \& Gregory, 1996; Firth, 1997; Mike et al., 1997; Naser \& Nuseibeh, 2008; Ellis \& Booker, 2011).

In the literature, several variables were used to proxy corporate size. The most widely used variables were total assets (e.g., Wallace \& Naser, 1996; Inchausti, 1997; Owusu-Ansah, 1998; Tower et al., 1999; Ho \& Wong, 2001; Naser et al., 2002; Camfferman \& Cooke, 2002; Abdul Hamid, 2004; Haniffa \& Cooke, 2005; Ali et al., 2004; Barako et al., 2006; Othman et al., 2009; Khan, 2010; Galani et al., 2011), total sales (e.g., Wallace et al., 1994; Meek et al., 1995; Inchausti, 1997; Depoers, 2000; Naser et al., 2002; Prencipe, 2004; Rouf, 2011) and market capitalization (e.g., Naser et al., 2006; Ghazali, 2007; Chatterjee \& Mir, 2008). Consistent with the findings of the majority of prior studies, it is, therefore, hypothesized that:

Hypothesis 1: Audit fees paid by Emirati nonfinancial companies listed on ADX are associated with corporate size.

\subsection{Profitability}

Previous research pointed to possible association between audit fees and corporate profitability (Joshi \& Al-Bastaki, 2000; Sandra \& Patrick, 1996). Companies reported high levels of profit would disclose more information to highlight their achievements and reduce agency costs (Watts \& Zimmerman, 1986). Disclosing more information will be used by management of a profitable company to signal information about their performance to strengthen their position and justify their compensation (Inchausti, 1997). These companies will be subject to rigorous audit testing to their revenues and expenses (Joshi \& Al-Bastaki, 2000). Hence, profitable companies would pay high audit fees. Different variables were employed by previous researchers to represent profitability. Among these variables are: net profits, net profit to sales, return on assets, and return on equity. It is, therefore, hypothesized that:

Hypothesis 2: Audit fees paid by Emirati nonfinancial companies listed on ADX are associated with corporate profitability.

\subsection{Second-Level Heading}

A level of corporate risk needs to be considered in defining audit work (AICPA, 2012). Corporate risk is viewed as being one of the main determinants of audit fees. Auditors need to make more efforts with a client with poor financial condition to avoid lawsuits against audit firms in the future, and thus, auditors will charge higher audit fees. Previous literature on the determinants of audit fees reported significant association with corporate risk (Simunic, 1980; Francis \& Stokes, 1986; Joshi \& Bastaki, 2000; Gonthier-Besacier \& Schatt, 2007). However, several studies reported insignificant relationship between the two variables (Vermeer et al., 2009; Ellis and Booker, 2011). In the literature, gearing ratios, and profitability ratios were used to proxy client's risk (Simunic, 1980; Francis \& Stokes, 1986; Chan et al., 1993; Joshi \& Al, B., 2000; Carson et al., 2004; Gonthier, B., \& Schatt, 2007). It is, therefore, hypothesized that:

Hypothesis 3: Audit fees paid by Emirati nonfinancial companies listed on ADX are associated with corporate risk. 


\subsection{Complexity}

Another variables used in previous research to explain audit fees is corporate complexity. Companies with several subsidiaries are considered to be more complex than companies with few or without subsidiaries. A significant proportion of previous studies observed positive relationship between corporate complexity and audit fees (Simunic, 1980; Brinn et al., 1994; Cameran, 2005; Joshi \& Bastaki, 2000; Clatworthy \& Peel, 2006; Thinggaard \& Kiertzner, 2008; Vermeer et al., 2009; Ellis \& Booker, 2011; Verbruggen et al., 2011). The main reasons advanced in the literature to explain such a relationship is that greater number of subordinate financial statements require more audit time and greater expertise to ensure the accuracy of the consolidated financial statements (Sandra \& Patrick, 1996). Moreover, auditing complex clients exposes external auditors to more professional liability claims than non-complex companies (Clatworthy \& Peel, 2006).In the literature, corporate complexity is measured by either the complexity of operations (e.g., Taylor \& Baker, 1981; Collier \& Gregory, 1996; Langendijk, 1997; Joshi \& Al, B., 2000) or the complexity of assets reported in the balance sheet (e.g., Chan et al., 1993, Peel \& Clatworthy, 2001; Simunic, 1980; Francis, 1984; Francis \& Stokes, 1986; Francis \& Simon, 1987; Simon \& Francis, 1988; Gonthier, B., \& Schatt, 2007). Consistent with previous research on the relationship between corporate complexity and audit fees, it is, therefore, hypothesized that:

Hypothesis 4: Audit fees paid by Emirati nonfinancial companies listed on ADX are associated with corporate complexity.

\subsection{Industry Type}

Previous research pointed to possible relationship between audit fees and corporate industry type. In this respect, Anderson and Zeghal (1994) showed that audit fees paid by Canadian transportation, communication, or utilities firms are lower than that paid by companies operating in other sectors. Gonthier-Besacier and Schatt (2007) found audit fees paid by French listed firms under the IT sector to be higher than that paid by firms belong to other sectors. Some industries require more external audit procedures and thus more audit fees to be paid by them in comparison with the other industries (Firth, 1985; Anderson \& Zeghal, 1994). The level of audit quality being demanded by manufacturing companies is higher than the level in other industries as manufacturing companies face higher levels of agency costs. Since manufacturing companies require big capital investment that forces them to look for external sources of funding, they are very likely to report more information than non-manufacturing ones in their annual reports to assure money providers (Naser \& Nuseibeh, 2008). Moreover, as manufacturing companies usually have negative impact on environment and the community, they are expected to face more public pressure than other companies. Hence, they would disclose detailed voluntary information to avoid public pressure and additional regulations (Hackston \& Milne, 1996; Tagesson, et al., 2009) as well as to legitimize their activities to a greater extent. Hiring high quality auditors is associated with high audit fees. Hence, audit fees paid to external auditors might be influenced by industry type. It is, therefore, hypothesized that:

Hypothesis 5: Audit fees paid by Emirati nonfinancial companies listed on ADX are associated with industry type.

\subsection{Status of the Audit Firm}

In the UAE, many audit companies and offices provide audit services for their clients. The audit firms are local, regional and big international. Previous researchers identified large audit firm as being one of the Big Four international audit firms, while other firms are viewed as being small (DeAngelo, 1981; Haniffa \& Cooke, 2002; Glaum \& Street, 2003). As large companies are usually more visible and accountable (Cormier \& Gordon, 2001) by the public and subject to political pressure more than small ones, they attempt to avoid such pressure, reduce monitoring costs and justify their existence in society by improving the quality of their reporting and recruiting big international audit firms. In return, big international audit firms are more likely to provide assurance to stockholders and reduce agency costs. Consequently, the reputation and status of audit firm can have a great effect on audit fees (Huang et al., 2007; Vermeer et al., 2009; Choi et al., 2010; Verbruggen et al., 2011; Wang et al., 2011; El-Gammal, 2012). In this respect, Hay et al., (2006) argued that higher audit fees are expected when an auditor is recognized to be of superior quality to other firms. It is, therefore, hypothesized that:

Hypothesis 6: Audit fees paid by Emirati nonfinancial companies listed on ADX are associated with the status of the audit firm employed by the company.

\subsection{Audit Report Lag}

An audit report lag is a period between a company's year-end date and the audit report date. A long audit report lag might reflect difficulties in the company, which in turn leads to an increase in audit fees either because 
greater audit work is required or due to additional risk involved. Prior literature showed a positive association between audit fees and the audit report lag (Chan et al., 1993; Ezzamel et al., 1996). It is, therefore, hypothesized that:

Hypothesis 7: Audit fees paid by Emirati nonfinancial companies listed on ADX are associated with audit report lag.

\subsection{Audit Committee Independence}

Previous research pointed to possible relationship between audit fees and the proportion of independent audit committee members. The direction of the relationship can be either way. The presence of qualified independent audit committee members would result in a high quality audit report in order to be viewed by the directorate as a means of enhancing their reputation as experts in decision control (Fama \& Jensen, 1983). This would result in high audit fees. On the other hand, the presence of qualified independent members on the committee would reduce audit risk assessment and, thus, resulted in less testing (Collier \& Gregory, 1996; Goddard \& Masters, 2000) which it turn reduces audit fees.

Ministerial Resolution No (518) of 2009 requires all companies listed in any stock exchange in the UAE to establish an audit committee. The Resolution indicated that the audit committee should have at least three non-executive directors, two of whom at least, must be independent directors, including its head.

Empirical evidence on the influence of the proportion of independent audit committee members on the audit fees is mixed. Some studies showed a positive relationship between firm's proportion of independent audit committee members and its audit fees (Abbott et al., 2003; Vafeas \& Waegelein, 2007). Other studies pointed to negative relationship between the two variables Collier and Gregory, 1996; Goddard and Masters, 2000. It is therefore, hypothesized:

Hypothesis 8: Audit fees paid by Emirati nonfinancial companies listed on ADX are associated with the proportion of the independent audit committee members.

It is evident from the literature review on the relationship between corporate audit fees and the discussed variables that there is no consensus on the level of the significance and the direction of the relationship. While some studies may find a positive association between a specific company's attribute and the audit fees, other researchers may find that this attribute either does not have influence, or even has a negative relationship with the fees paid to external auditors.

\section{Data Collection and Methodology}

As mentioned earlier, Emirati nonfinancial companies listed on ADX are covered in this study. By the end of 2011, the total number of companies listed on ADX was 65. This number includes 5 non-Emirati companies. The Emirati companies listed on the exchange are divided into 30 financial companies (14 banks and 16 insurance companies) and 30 nonfinancial. Drawing from previous studies on audit fees, financial companies are excluded from the current study since these companies have special nature of activities and they have different fees structure than the nonfinancial companies (Basioudis \& Fifi, 2004; Cameran, 2005; Simunic, 1980). Thus, the 2011 annual reports together with the governance reports for all companies listed on ADX were covered in the current study.

The association between audit fees paid by Emirati nonfinancialcompanies listed on ADX and the firms' attributes discussed in the previous section is expressed in the following regression model.

$$
\text { ADFEES }=f(\text { SIZE, PROF, RISK, COM, INDS, AUST, ARL, INDCOM })
$$

Where:

$\begin{array}{rlrl} & \text { ADFEES } & = & \text { Audit fees } \\ (+) & \text { SIZE }= & \text { Corporate size measured by the natural logarithm of the company's total assets. } \\ (+) & \text { PROF }= & \text { Profitability measured by net income/ sales } \\ (+) & \text { RISK }= & \text { Risk measured by total liabilities/ total assets } \\ \left(^{+}\right) & \text {COMP } & \text { Corporate complexity measured by the number of subsidiaries } \\ ( \pm) & I N D S= & \text { Industry } \\ (+) & A U S T= & \text { Status of the audit firm; }(0) \text { score is given to a local audit firm and (1) score is given to } \\ & & \text { a local firm affiliated to a big international firm. }\end{array}$




$$
\begin{aligned}
& \text { (+) } A R L=\text { The lag between the audit report and the end of the accounting year } \\
& (-) A D C O M=\text { The proportion of independent members on the audit committee }
\end{aligned}
$$

\section{Findings}

\subsection{Descriptive Statistics}

Descriptive statistics concerning dependent and independent variables employed in this study are presented in tables 1and 2. Table 1 shows that Emirati nonfinancial companies listed on ADX vary in their characteristics. Audit fees paid by the companies range from AED 70,000 to AED 3,177,435 with a mean of AED 412,692 (audit fees in logarithms range from UAE Dirham AED 4.85 to AED 6.5 with a mean of AED 5.43). Companies' sizes measured by the natural logarithm of the company's total assets varied greatly. The total assets (in logarithms) range from 8.57.84 to AED 11.06, with a mean of AED 9.43 AED. Over all observations that formed the sample, profitability ranges from -0.13 to 0.53 , with a mean of 0.094 . Risk ranges between 0.07 and 0.89 , with a mean of 0.39 . A ratio of 0.89 implies that the company depends heavily on debt and has little equity. The standard deviation of the leverage ratio together with the minimum and maximum amounts pointed to major variations in the level of leverage among the surveyed companies. The complexity of the surveyed companies ranges from 0 to 19 . A zero figure means that some companies had no subsidiaries, while a figure of 19 implies that the company is very complex as it has 19 subsidiaries.

Concerning the independent audit committee variable, Table 1 shows that the proportion of independent audit committee members to total number of the committee ranges from 0.67 to 1 with a mean of 0.90 percent. The high proportion of independent audit committee members is a reflection of what is required by Resolution No (518) of 2009. It requires audit committee to have at least three directors, two of whom at least, must be independent directors. It can be also observed from Table 2 that the majority of non-financial companies included in the study (60 percent) are manufacturing companies. As for auditor type, 24 (or 80 percent) annual reports were audited by audit firms with an international affiliation (Big Four) whilst 6 (20 percent) were not. The auditing in the UAE is clearly dominated by local firms affiliated to big international audit firms.

\begin{tabular}{|c|c|c|c|c|c|}
\hline Variable & Mean & Median & $\begin{array}{l}\text { Standard } \\
\text { Deviation }\end{array}$ & Minimum & Maximum \\
\hline Audit Fees (ADFEES) & 5.43 & 5.36 & 0.07 & 4.85 & 6.50 \\
\hline Total assets in logarithms (SIZ) & 9.43 & 9.25 & 0.12 & 8.57 & 11.06 \\
\hline Net income / Net sales (PROF) & 0.09 & 0.10 & 0.03 & -0.13 & 0.53 \\
\hline Total liabilities/ Total assets (RISK) & 0.40 & 0.40 & 0.04 & 0.07 & 0.89 \\
\hline Number of subsidiaries (COMP) & 5.17 & 2.50 & 1.07 & 0.00 & 19.00 \\
\hline Audit Report Lag (ARL) in days & 62.33 & 64.00 & 3.49 & 33.00 & 91.00 \\
\hline $\begin{array}{l}\text { The proportion of independent members on the audit } \\
\text { committee (ADCOM) }\end{array}$ & 0.90 & 1.00 & 0.03 & 0.67 & 1.00 \\
\hline
\end{tabular}

Table 1. Descriptive statistics about continuous variables employed in the study

Table 2. Descriptive statistics about discontinuous variables employed in the study

\begin{tabular}{lllll}
\hline Variable & & Frequency & Percentage & $\begin{array}{l}\text { Accumulated } \\
\text { percentage }\end{array}$ \\
\hline Audit Firm Status (SAF) & International & 24 & 80 & 80 \\
& Otherwise & 6 & 20 & 100 \\
Industry (IND) & Industrial & 17 & 56.7 & 56.7 \\
& Service & 6 & 20 & 76.7 \\
& Consumers staples & 7 & 23.3 & 100 \\
\hline
\end{tabular}




\subsection{Correlation}

To examine the association between various variables utilized in this study, the Pearson correlation coefficient matrix is performed and presented in Table 3. The Table reveals a number of significant correlations among the dependent and independent variables. The analysis shows that there is a significant positive association between audit fees and each of company size, complexity, and status of audit firm. A positive but insignificant association was observed between the audit fees and both the profitability and risk variables. On the other hand, audit fees are negatively associated with each of industry type, the lag between the audit report and the end of the accounting year, and the proportion of independent members on the audit committee.

The Pearson correlation matrix also shows a number of strong correlations between some explanatory variables (e.g., size and complexity, size and risk, risk and complexity, and profitability with industry type). This implies the possibility of multicollinearity problems. The largest reported correlation value among the variables as shown in Table 3 (0.796) was between size and complexity variables. However, this value is still lower than the critical value of 0.80 (Judge et al., 1988; Bryman \& Cramer, 2005). Hence, multicollinearity between the independent variables is not considered a serious problem. Moreover, Table 4 shows that all of the resulted VIF is well below the critical value of 10. According to Neter et al. (1989), the VIF value of less than 10 indicates that multicollinearity is not a serious concern in the interpretation of the findings of the OLS regression.

\subsection{Regression Analysis}

As the correlation test and the VIF test showed that no significant multicollinearity problem among the independent variables has been detected, a multivariate test using the regression model was performed on all independent variables. In this study, backward regression was performed. Under this regression, independent variables insignificantly associated with audit fees are sequentially removed from the regression model until obtaining the best fit model. The findings are presented in Table 4.

It can be observed in Table 4 that both the F-value of $13.289(\mathrm{P}=0.00)$ and the adjusted $\mathrm{R} 2$ of the first regression model $77.2 \%$ support the significance of the model and suggest that the independent variables employed in the model explain more than $77 \%$ of the variation in audit fees paid by Emirati nonfinancial companies listed on ADX. Table 4 also reported a positive and significant association between audit fees and each of corporate size, complexity, and status of audit firm. A negative and significant association was also detected between audit fees and each of the industry type and the proportion of independent members on the audit committee.

A strong and positive association between audit fees and the size of the Emirati nonfinancial companies listed on ADX provides evidence that company size is one of the most important variables in explaining variations in the audit fees. This finding is consistent with prior studies that suggested firm size as one of the main determinants of the audit fees (e.g., Chan et al., 1993; Pong \& Whittington, 1994; Che Ahmad, \& Derashid, 1996; Ezzamel et al., 1996; Gregory \& Collier, 1996; Iyer \& Iyer, 1996; Joshi \& Al, B., 2000; Naser \& Nuseibeh, 2008).

The second variable appeared to be a significant predictor of audit fees of the Emirati nonfinancial companies listed on ADX is company's complexity as measured by number of subsidiaries. This finding is in line with some prior studies (Firth, 1985; Simon et al., 1992; Iyer \& Iyer, 1993; Pong \& Wittington, 1994; Johnson et al., 1995; Collier \& Gregory, 1996; Sandra \& Patrick, 1996; Mike, 1997; Langendijk; Joshi \& Al-Bastaki, 2000). The strong association observed between audit fees and company's complexity is justified on grounds that a more complex company (measured by the number of subsidiaries) requires more audit work to examine individual company financial statements and consolidated financial statements. Moreover, the auditor needs to perform more complicated audit procedures when the company has foreign subsidiaries for making sure of the company's compliance with the rules and regulations imposed by home country and, therefore, the company will be subject to higher audit fees.

Consistent with expectation, the audit report lag has been found to be one of the main factors influencing the audit fees paid by Emirati non-financial companies listed on ADX. A longer audit report lag might point to accounting problems that may require greater audit work and hence higher audit fees. This result reinforces the findings in some previous studies (Haskins \& Williams, 1988; Chan et al., 1993; Che Ahmad \& Derashid, 1996; Ezzamel et al., 1996; Craswell \& Francis, 1999).This result is, however, inconsistent with Naser and Nuseibeh (2008) who found that audit report lag was insignificant in explaining the variations in audit fees among Jordanian listed companies.

As predicted, regression results indicated that there is a significant negative relationship betweenaudit committee independence and audit fees. While this result supports the findings of some prior literature that showed significant and inverse relationship between the two variables (Collier \& Gregory, 1996; Goddard \& Masters, 2000), it disagrees with findings from other research studies that showed a positive relationship between company's independence of audit committee and its audit fees (Abbott et al., 2003; Vafeas \& Waegelein, 2007). This finding can be explained 
on the grounds that audit committee with more independent members will reduce external auditor's risk assessment and, thus, reduces the scope of the audit (Collier \& Gregory, 1996; Goddard \& Masters, 2000) which leads to lower audit fees.

The findings also showed that audit fees are negatively and significantly associated with industry. This implies that manufacturing companies pay lower fees than those in service and consumer staples sectors. A possible explanation for this finding may be that Emirati manufacturing companies might be considered small companies in comparison to manufacturing companies in both developed and industrialized emerging economies, and thus, these companies are not requiring higher audit quality than other companies belong to other sectors. Another explanation to this result is that limited number of companies are listed on ADX. In return, many audit firms are operating in Abu Dhabi. This leads to imbalance between the supply and demand for external. This situation would strengthen the bargaining power of the manufacturing companies and reduces audit fees.

\section{Conclusion}

It was evident that limited research on the determinants of audit fees has been undertaken in the Arab and Middle Eastern countries. This is due to the fact that companies in this part of the world do not publish information about audit fees. However, in 2009 the Ministry of Economy in the UAE issued Ministerial Resolution No. 518 concerning Governance Rules and Corporate Discipline Standards and requested all nonfinancial companies listed on ADX to disclose audit fees with effect from April 2010. Hence, nonfinancial companies listed on ADX started to disclose information about audit fees in their 2011 annual report for the first time. This emerging opportunity motivates the current research which is expected to expand a limited existing audit fees literature in the Arab and Middle Eastern countries. Needless to say that UAE has unique features since it is one of the fastest

Table 3. Correlation among all variables used in the study

\begin{tabular}{|c|c|c|c|c|c|c|c|c|c|c|}
\hline Variable & & ADFEES & SIZ & PROF & RISK & COMP & IND & SFA & ARL & AUDCOM \\
\hline \multirow[t]{2}{*}{ ADFEES } & Pearson Correlation & 1.000 & & & & & & & & \\
\hline & Sig. (2-tailed) & 0.000 & & & & & & & & \\
\hline \multirow[t]{2}{*}{ SIZ } & Pearson Correlation & $.824 * *$ & 1.000 & & & & & & & \\
\hline & Sig. (2-tailed) & 0.000 & 0.000 & & & & & & & \\
\hline \multirow[t]{2}{*}{ PROF } & Pearson Correlation & 0.264 & 0.235 & 1.000 & & & & & & \\
\hline & Sig. (2-tailed) & 0.144 & 0.196 & 0.000 & & & & & & \\
\hline \multirow[t]{2}{*}{ RISK } & Pearson Correlation & 0.327 & $.482 * *$ & 0.118 & 1.000 & & & & & \\
\hline & Sig. (2-tailed) & 0.068 & 0.005 & 0.518 & 0.000 & & & & & \\
\hline \multirow[t]{2}{*}{ COMP } & Pearson Correlation & $.755 * *$ & $.791 * *$ & 0.349 & $.623 * *$ & 1.000 & & & & \\
\hline & Sig. (2-tailed) & 0.000 & 0.000 & 0.050 & 0.000 & 0.000 & & & & \\
\hline \multirow[t]{2}{*}{ IND } & Pearson Correlation & -0.092 & 0.059 & $-.468 * *$ & 0.143 & -0.073 & 1.000 & & & \\
\hline & Sig. (2-tailed) & 0.615 & 0.750 & 0.007 & 0.435 & 0.692 & 0.000 & & & \\
\hline \multirow[t]{2}{*}{ SFA } & Pearson Correlation & $.421^{*}$ & $.438^{*}$ & 0.307 & 0.048 & 0.196 & 0.061 & 1.000 & & \\
\hline & Sig. (2-tailed) & 0.017 & 0.012 & 0.087 & 0.793 & 0.284 & 0.742 & 0.000 & & \\
\hline \multirow[t]{2}{*}{ ARL } & Pearson Correlation & -0.062 & -0.013 & -0.050 & 0.127 & 0.105 & 0.009 & 0.050 & 1.000 & \\
\hline & Sig. (2-tailed) & 0.734 & 0.943 & 0.787 & 0.488 & 0.569 & 0.963 & 0.785 & 0.000 & \\
\hline \multirow[t]{2}{*}{ AUDCOM } & Pearson Correlation & -0.071 & 0.155 & $.397^{*}$ & 0.221 & 0.201 & -0.087 & 0.285 & 0.000 & 1.000 \\
\hline & Sig. (2-tailed) & 0.701 & 0.396 & 0.024 & 0.225 & 0.269 & 0.636 & 0.114 & 0.998 & 0.000 \\
\hline
\end{tabular}

**. Correlation is significant at the 0.01 level (2-tailed).

*. Correlation is significant at the 0.05 level (2-tailed). 
Table 4. Results of the back word regression analysis

\begin{tabular}{|c|c|c|c|c|c|}
\hline Model & & Variables & $\mathrm{R} 2=. .835$ & Adj. $\mathrm{R} 2=.772$ & $F=13.289$ \\
\hline & & Beta & $\mathrm{T}$ & Sig. & VIF \\
\hline & (Constant) & 3.646 & 3.924 & 0.001 & \\
\hline \multirow[t]{11}{*}{1} & SIZ & 0.264 & 2.631 & 0.016 & 3.97 \\
\hline & PROF & -0.069 & -0.233 & 0.818 & 1.917 \\
\hline & RISK & -0.16 & -0.844 & 0.408 & 1.83 \\
\hline & COMP & 0.031 & 2.664 & 0.015 & 4.377 \\
\hline & IND & -0.117 & -1.459 & 0.159 & 1.554 \\
\hline & SAF & 0.241 & 2.312 & 0.031 & 1.757 \\
\hline & $\mathrm{ARL}$ & -0.002 & -1.355 & 0.19 & 1.118 \\
\hline & $\mathrm{ADCOM}$ & -0.848 & -3.152 & 0.005 & 1.426 \\
\hline & & Variables & $\mathrm{R} 2=. .835$ & Adj. $R 2=.782$ & $F=15.862$ \\
\hline & & Beta & $\mathrm{T}$ & Sig. & VIF \\
\hline & (Constant) & 3.615 & 4.018 & 0.001 & \\
\hline \multirow[t]{10}{*}{2} & SIZ & 0.268 & 2.774 & 0.011 & 3.849 \\
\hline & RISK & -0.159 & -0.856 & 0.401 & 1.829 \\
\hline & COMP & 0.03 & 2.781 & 0.011 & 3.975 \\
\hline & IND & -0.108 & -1.551 & 0.135 & 1.237 \\
\hline & SAF & 0.233 & 2.412 & 0.025 & 1.582 \\
\hline & ARL & -0.002 & -1.364 & 0.186 & 1.092 \\
\hline & ADCOM & -0.863 & -3.373 & 0.003 & 1.347 \\
\hline & & Variables & $\mathrm{R} 2=.829$ & Adj. $R 2=.785$ & $F=18.599$ \\
\hline & & Beta & $\mathrm{T}$ & Sig. & VIF \\
\hline & (Constant) & 3.644 & 4.076 & 0 & \\
\hline \multirow[t]{9}{*}{3} & SIZ & 0.266 & 2.768 & 0.011 & 3.846 \\
\hline & COMP & 0.026 & 2.672 & 0.014 & 3.383 \\
\hline & IND & -0.126 & -1.886 & 0.072 & 1.136 \\
\hline & SAF & 0.249 & 2.631 & 0.015 & 1.527 \\
\hline & ARL & -0.003 & -1.481 & 0.152 & 1.077 \\
\hline & ADCOM & -0.912 & -3.675 & 0.001 & 1.281 \\
\hline & & Variables & $\mathrm{R} 2=.813$ & Adj. $R 2=.774$ & $F=20.844$ \\
\hline & & Beta & $\mathrm{T}$ & Sig. & VIF \\
\hline & (Constant) & 3.209 & 3.709 & 0.001 & \\
\hline \multirow[t]{5}{*}{4} & SIZ & 0.295 & 3.064 & 0.005 & 3.683 \\
\hline & COMP & 0.023 & 2.325 & 0.029 & 3.179 \\
\hline & IND & -0.125 & -1.83 & 0.08 & 1.136 \\
\hline & ARL & 0.226 & 2.363 & 0.027 & 1.486 \\
\hline & ADCOM & -0.869 & -3.442 & 0.002 & 1.264 \\
\hline
\end{tabular}

In consistent with Naser and Nuseibeh (2008) who found that audit report lag was insignificant in explaining the variations in audit fees among Jordanian listed companies.

growing economies in the world and Abu Dhabi hosts one of the youngest stock exchanges in the region. Also, companies in the UAE are exempted from paying income tax. In addition, a limited number of companies are listed on the exchange with many local, regional and international audit firms operating in the UAE. This creates 
an imbalance between the supply and demand for external audit and return affect audit fees. Consequently, studying the relationship between audit fees and companies attributes within these unique features will add a new dimension to the literature.

To identify companies attributes that impact audit fees by Emirati nonfinancial companies listed on ADX, the 2011 annual financial and governance reports for all these companies were used. Audit fees and eight attributes of the companies were extracted from the reports. The attributes include: size measured by total assets, profitability measured by net income to sales, risk measured by total liabilities to total assets, complexity measured by the number of subsidiaries, industry type, status of the audit firm, audit report lag measured by lag between the audit report and the end of the accounting year and audit committee independence measured by the proportion of independent members on the audit committee.

To identify corporate attributes responsible for variations in audit fees paid by Emirati nonfinancial companies listed on ADX, A backward regression analysis was performed. The outcome of the analysis showed that external audit fees are positively and significantly related with company size, business complexity, and audit report lag. Audit fees, however, is negatively and significantly associated with industry type and audit committee independence. The present finding seems to be consistent with other research in some developed and emerging economies.

\section{References}

Abbott, L. J., Parker, S., Peters, G. F., \& Raghunandan, K. (2003).The association between audit committee characteristics and audit fees. Auditing: A Journal of Practice \& Theory, 22(2), 17-32.

AICPA. (2012). Code of Professional Conduct and Bylaws. New York: American Institute of Certified Public Accountants, Inc.

Ali, M. J., Ahmed, K., \& Henry, D. (2004). Disclosure compliance with national accounting standards by listed companies in South Asia. Accounting and Business Research, 34(3), 183-199. http://dx.doi.org/10.1080/00014788.2004.9729963

Anderson, T., \& Zeghal, D. (1994). The pricing of audit services: Further evidence from the Canadian market. Accounting and Business Research, 24(95), 195-207. http://dx.doi.org/10.1080/00014788.1994.9729479

Barako, D. G., Hancock, P., \& Izan, H. Y. (2006). Factors influencing voluntary corporate disclosure by Kenyan companies. Corporate Governance: An International Review, 14(2), 107-125.

Basioudis, I. G., \& Fifi, F. (2004). The market for professional services in Indonesia. International Journal of Auditing, 8(2), 153-164. http://dx.doi.org/10.1111/j.1099-1123.2004.00087.x

Brinn, T., Peel, M. J., \& Roberts, R. (1994). Audit fee determinants of independent \& subsidiary unquoted companies in the UK-an exploratory study. The British Accounting Review, 26(2), 101-121. http://dx.doi.org/10.1006/bare.1994.1009

Bryman, A., \& Cramer, D. (2005). Quantitative data analysis with SPSS 12 and 13: A guide for social scientist. Routledge.

Cameran, M. (2005). Audit fees and the large auditor premium in the Italian market. International Journal of Auditing, 9(2), 129-146. http://dx.doi.org/10.1111/j.1099-1123.2005.00205.x

Camfferman, K., \& Cooke, T. E. (2002). An analysis of disclosure in the annual reports of UK and Dutch companies. Journal of International Accounting Research, 1(1), 3-30. http://dx.doi.org/10.2308/jiar.2002.1.1.3

Carson, E., Fargher, N., Simon, D. T., \& Taylor, M. H. (2004). Audit fees and market segmentation-further evidence on how client size matters within the context of audit fee models. International Journal of Auditing, 8(1), 79-91. http://dx.doi.org/10.1111/j.1099-1123.2004.00159.x

Chan, P., Ezzamel, M., \& Gwilliam, D. (1993). Determinants of audit fees for quoted UK companies. Journal of Business Finance \& Accounting, 20(6), 765-786. http://dx.doi.org/10.1111/j.1468-5957.1993.tb00292.x

Chatterjee, B., \& Mir, M. Z. (2008). The current status of environmental reporting by Indian companies. Managerial Auditing Journal, 23(6), 609-629. http://dx.doi.org/10.1108/02686900810882138

Che, A. A., \& Derashid. C. (1996 July). The Pricing of audit services: Evidence from the Kuala Lumpur stock exchange (KLSE) listed companies. Journal Analysis, 4(1), 4-45.

Choi, J. H., Kim, C., Kim, J. B., \& Zang, Y. (2010). Audit office size, audit quality, and audit pricing. Auditing: A 
Journal of Practice \& Theory, 29(1), 73-97.

Clatworthy, M. A., \& Peel, M. J. (2006). The effect of corporate status on external audit fees: Evidence from the UK. Journal of Business Finance and Accounting, l(2), 169-201.

Collier, P., \& Gregory, A. (1996). Audit committee effectiveness and the audit fee. European Accounting Review, 5(2), 177-198. http://dx.doi.org/10.1080/09638189600000012

Craswell, A. T., \& Francis, J. R. (1999). Pricing initial audit engagements: A test of competing theories. The Accounting Review, 74(2), 201-216. http://dx.doi.org/10.2308/accr.1999.74.2.201

DeAngelo, L. E. (1981). Auditor size and audit quality. Journal of Accounting and Economics, 3(3), 183-199. http://dx.doi.org/10.1016/0165-4101(81)90002-1

Denis, C. D., \& Gordon, I. R. (2001). An examination of social and environmental reporting strategies. $\begin{array}{lllll}\text { Accounting, Auditing \& } \quad \text { Accountability Journal, } & \text { 14(5), }\end{array}$ http://dx.doi.org/10.1108/EUM0000000006264

Depoers, F. (2000). A cost benefit study of voluntary disclosure: Some empirical evidence from French listed companies. European Accounting Review, 9(2), 245-263. http://dx.doi.org/10.1080/09638180050129891

El-Gammal, W. (2012). Determinants of audit fees: Evidence from Lebanon. International Business Research, 5(11), 136-145. http://dx.doi.org/10.5539/ibr.v5n11p136

Ellis, Y., \& Booker, Q. L. (2011). Audit fee determinants in the nonprofit sector: A study of community action agencies. Columbia State University: Faculty Publications.

Ezzamel, M., Gwilliam, D. R., \& Holland, K. M. (1996). Some empirical evidence from publicly quoted UK companies on the relationship between the pricing of audit and non-audit services. Accounting and Business Research, 27(1), 3-16. http://dx.doi.org/10.1080/00014788.1996.9729528

Ezzamel, M., Gwilliam, D. R., \& Holland, K. M. (2002). The Relationship between Categories of Non-Audit Services and Audit Fees: Evidence from UK Companies. International Journal of Auditing, 6(1), 13-35. http://dx.doi.org/10.1111/j.1099-1123.2002.tb00003.x

Fama, E. F., \& Jensen, M. C. (1983). Separation of Ownership and Control. Journal of Law \& Economics, 26, 301-25. http://dx.doi.org/10.1086/467037

Firth, M. (1985). An analysis of audit fees and their determinants in New Zealand. Auditing: A Journal of Practice and Theory, 4(2), 23-37.

Firth, M. (1997). The Provision of Non-audit Services and the Pricing of Audit Fees. Journal of Business Finance \& Accounting, 24(3), 511-525. http://dx.doi.org/10.1111/1468-5957.00118

Francis, J. R. (1984). The effect of audit firm size on audit prices: A study of the Australian market. Journal of Accounting and Economics, 6(2), 133-151. http://dx.doi.org/10.1016/0165-4101(84)90010-7

Francis, J. R., \& Simon, D. T. (1987). A test of audit pricing in the small-client segment of the US audit market. Accounting Review, 62(1), 145-157.

Francis, J. R., \& Stokes, D. J. (1986). Audit prices, product differentiation, and scale economies: further evidence from the Australian market. Journal of Accounting Research, 24, 383-393. http://dx.doi.org/10.2307/2491141

Galani, D., Alexandridis, A., \& Stavropoulos, A. (2011). The Association between the firm characteristics and corporate mandatory disclosure: the Case of Greece. World Academy of Science, Engineering and Technology, 77, 101-107.

Ghazali, N. A. M. (2007). Ownership structure and corporate social responsibility disclosure: some Malaysian evidence. Corporate Governance, 7(3), 251-266. http://dx.doi.org/10.1108/14720700710756535

Glaum, M., \& Street, D. L. (2003). Compliance with the disclosure requirements of Germany's new market: IAS versus US GAAP. Journal of International Financial Management and Accounting, 14, 64-100. http://dx.doi.org/10.1111/1467-646X.00090

Goddard, A. R., \& Masters, C. (2000). Audit committees, Cadbury Code and audit fees: an empirical analysis of UK companies. Managerial Auditing Journal, 15(7), 358-371. http://dx.doi.org/10.1108/02686900010344638

Gonthier, B. N., \& Schatt, A. (2007). Determinants of audit fees for French quoted firms. Managerial Auditing 
Journal, 22(2), 139-160. http://dx.doi.org/10.1108/02686900710718654

Gregory, A., \& Collier, P. (1996). Audit fees and auditor change: an investigation of the persistence of fee reduction by type of change. Journal of Business Finance \& Accounting, 23(1), 13-28. http://dx.doi.org/10.1111/j.1468-5957.1996.tb00399.x

Hackston, D., \& Milne, M. J. (1996). Some determinants of social and environmental disclosures in New Zealand companies. Accounting, Auditing \& Accountability Journal, 9(1), 77-108. http://dx.doi.org/10.1108/09513579610109987

Hamid, F. A. (2004). Corporate social disclosure by banks and finance companies: Malaysian evidence. Corporate Ownership and Control, 1(4), 118-130.

Haniffa, R. M., \& Cooke, T. E. (2002). Culture, corporate governance and disclosure in Malaysian corporations. Abacus, 38(3), 317-349. http://dx.doi.org/10.1111/1467-6281.00112

Haniffa, R., \& Cooke, T. (2005). The impact of culture and governance on corporate social reporting. Journal of Accounting and Public Policy, 24(5), 391-430. http://dx.doi.org/10.1016/j.jaccpubpol.2005.06.001

Haskins, M. E., \& Williams, D. D. (1988). The association between client factors and audit fees: A comparison by country and by firm. Accounting and Business Research, 18(70), 183-190. http://dx.doi.org/10.1080/00014788.1988.9729363

Hay, D. C., Knechel, W. R., \& Wong, N. (2006). Audit fees: A Meta-analysis of the effect of supply and demand attributes. Contemporary Accounting Research, 23(1), 141-191. http://dx.doi.org/10.1506/4XR4-KT5V-E8CN-91GX

Huang, H. W., Liu, L. L., Raghunandan, K., \& Rama, D. V. (2007). Auditor industry specialization, client bargaining power, and audit fees: Further evidence. Auditing: A Journal of Practice \& Theory, 26(1), 147-158.

Inchausti, A. G. (1997). The influence of company characteristics and accounting regulation on information disclosed by Spanish firms. European Accounting Review, 6(1), 45-68. http://dx.doi.org/10.1080/096381897336863

Iyer, V. M., \& Iyer, G. S. (1996). Effect of Big 8 mergers on audit fees: Evidence from the United Kingdom. Auditing, 15, 123-132.

Johnson, E. N., Walker, K. B., Westergaard, E. (1995). Supplier concentration and pricing of audit services in New Zealand. Auditing: A Journal of Practice and Theory, 14, 74-89.

Joshi, P., \& AL-Bastaki, H. (2000). Determinants of audit fees: evidence from the companies listed in Bahrain. International journal of auditing, 4(2), 129-138. http://dx.doi.org/10.1111/1099-1123.00308

Judge, G. G., Hill, R. C., Griffiths, W. E., Luetkepohl, H., \& Lee, T. C. (1988). Introduction to the theory and practice of econometrics. New York: John Willey \& Sons Inc.

Khan, M. H. U. Z. (2010). The effect of corporate governance elements on corporate social responsibility (CSR) reporting: empirical evidence from private commercial banks of Bangladesh. International Journal of Law and Management, 52(2), 82-109. http://dx.doi.org/10.1108/17542431011029406

Kutob, A., \& Al-Khater, K. (2004). An empirical investigation of factors affecting audit fees: The case study of Qatar. King Abdul-Aziz University Journal for Economics and Management, 18(2), 153-188.

Langendijk, H. (1997). The market for audit services in the Netherlands. European Accounting Review, 6(2), 253-264. http://dx.doi.org/10.1080/096381897336791

Meek, G. K., Roberts, C. B., \& Gray, S. J. (1995). Factors influencing voluntary annual report disclosures by US, UK and continental European multinational corporations. Journal of International Business Studies, 26(3), 555-572. http://dx.doi.org/10.1057/palgrave.jibs.8490186

Mike, A., Mike, S., \& Muhammad, H. (1997) The Determinants of External Audit Costs in the New Zealand Life Insurance Industry. Journal of International Financial Management and Accounting, 8, 69-86. http://dx.doi.org/10.1111/1467-646X.00018

Naser, K., \& Nuseibeh, R. (2008). Determinants of audit fees: empirical evidence from an emerging economy. International Journal of Commerce and Management, 17(3), 239-254. http://dx.doi.org/10.1108/10569210710833635

Naser, K., Al, H. A., Al-Kwari, D., \& Nuseibeh, R. (2006). Determinants of corporate social disclosure in 
developing countries: the case of Qatar. Advances in International Accounting, 19, 1-23. http://dx.doi.org/10.1016/S0897-3660(06)19001-7

Naser, K., Al-Khatib, K., \& Karbhari, Y. (2002). Empirical evidence on the depth of corporate information disclosure in developing countries: the case of Jordan. International Journal of Commerce and Management, 12(3/4), 122-155. http://dx.doi.org/10.1108/eb047456

Neter, J., Wasserman, W., \& Kutner, M. H. (1989). Applied linear regression models. Homewood, IL: Irwin.

Niemi, L. (2006). Do firms pay for audit risk? Evidence on risk premiums in audit fees after direct control for $\begin{array}{lllll}\text { audit effort. International Journal of Auditing, } & \text { 6(1), }\end{array}$ http://dx.doi.org/10.1111/j.1099-1123.2002.tb00004.x

Othman, R., \& Thani, M. G. (2009). Determinants of Islamic social reporting among top Shariah-approved companies in Bursa Malaysia. Research Journal of International Studies, 12, 4-20.

Owusu, A. S. (1998). The impact of corporate attributes on the extent of mandatory disclosure and reporting by listed companies in Zimbabwe. The International Journal of Accounting, 33(5), 605-631. http://dx.doi.org/10.1016/S0020-7063(98)90015-2

Palmrose, Z. V. (1986). Audit fees and auditor size: Further evidence. Journal of Accounting Research, 24(1), 97-110. http://dx.doi.org/10.2307/2490806

Peel, M. J., \& Clatworthy, M. A. (2001). The relationship between governance structure and audit fees pre-Cadbury: some empirical findings. Corporate Governance: An International Review, 9(4), 286-297.

Pong, C. M., \& Whittington, G. (1994). The determinants of audit fees: Some empirical models. Journal of Business Finance \& Accounting, 21(8), 1071-1095. http://dx.doi.org/10.1111/j.1468-5957.1994.tb00365.x

Prencipe, A. (2004). Proprietary costs and determinants of voluntary segment disclosure: evidence from Italian listed companies. European Accounting Review, 13(2), 319-340. http://dx.doi.org/10.1080/0963818042000204742

Rouf, A. (2011). Corporate characteristics, governance attributes and the extent of voluntary disclosure in Bangladesh. African Journal of Business Management, 5(19), 7836-7845.

Sandra, W., \& Patrick, P. (1996). The determinants of audit fees in Hong Kong: An empirical study. Asian Review of Accounting, 4(2), 32-50. http://dx.doi.org/10.1108/eb060673

Simon, D. T., \& Francis, J. R. (1988). The effects of auditor change on audit fees: Tests of price cutting and price recovery. Accounting Review, 63(2), 255-269.

Simon, D. T., \& Taylor, M. H. (2002). A survey of audit pricing in Ireland. International Journal of Auditing, 6(1), 3-12. http://dx.doi.org/10.1111/j.1099-1123.2002.tb00002.x

Simon, D., Ramanan, R., \& Dugar, A. (1986). The market for audit services in India: an empirical examination. International Journal of Accounting, 21(1), 285-295.

Simon, D., Teo, S., \& Trompeter, G. (1992). A comparative study of the market for audit services in Hong Kong, Malaysia and Singapore. International Journal of Accounting, 27, 234-253.

Simunic, D. A. (1980). The pricing of audit services: Theory and evidence. Journal of Accounting Research, 18(1), 161-190. http://dx.doi.org/10.2307/2490397

Tagesson, T., Blank, V., Broberg, P., \& Collin, S. O. (2009). What explains the extent and content of social and environmental disclosures on corporate websites: a study of social and environmental reporting in Swedish listed corporations. Corporate Social Responsibility and Environmental Management, 16(6), 352-364. http://dx.doi.org/10.1002/csr.194

Taylor, M. E., \& Baker, R. L. (1981). An analysis of the external audit fee. Accounting and Business Research, 12, 55-60. http://dx.doi.org/10.1080/00014788.1981.9728789

Thinggaard, F., \& Kiertzner, L. (2008). Determinants of audit fees: evidence from a small capital market with a joint audit requirement. International Journal of Auditing, 12(2), 141-158. http://dx.doi.org/10.1111/j.1099-1123.2008.00377.x

Tower, G., Hancock, P., \& Taplin, R. H. (1999). A regional study of listed companies' compliance with International Accounting Standards. Accounting Forum, 23(3), 293-305. http://dx.doi.org/10.1111/1467-6303.00016 
Vafeas, N., \& Waegelein, J. F. (2007). The association between audit committees, compensation incentives, and corporate audit fees. Review of Quantitative Finance and Accounting, 28(3), 241-255. http://dx.doi.org/10.1007/s11156-006-0012-9

Verbruggen, S., Christiaens, J., Reheul, A. M., \& Van Caneghem, T. (2011). Audit pricing in a reformed nonprofit market. HUB Research Papers.

Vermeer, T. E., Raghunandan, K., \& Forgione, D. A. (2009). Audit fees at US non-profit organizations. Auditing: A Journal of Practice \& Theory, 28(2), 289-303. http://dx.doi.org/10.2308/aud.2009.28.2.289

Wallace, R. O., Naser, K., \& Mora, A. (1994). The relationship between the comprehensiveness of corporate annual reports and firm characteristics in Spain. Accounting and Business Research, 25, 41-53.

Wallace, R., \& Naser, K. (1996). Firm-specific determinants of the comprehensiveness of mandatory disclosure in the corporate annual reports of firms listed on the stock exchange of Hong Kong. Journal of Accounting and Public policy, 14(4), 311-368. http://dx.doi.org/10.1016/0278-4254(95)00042-9

Wang, K., Sewon, O., \& Iqbal, Z. (2009). Audit pricing and auditor industry specialization in an emerging market: Evidence from China. Journal of International Accounting, Auditing and Taxation, 18, 60-72. http://dx.doi.org/10.1016/j.intaccaudtax.2008.12.006

Wang, K., Sewon, O., Iqbal, Z., \& Smith, L. M. (2011). Auditor Market Share and Industry Specialization of Non-Big 4 Firms. Journal of Accounting and Finance, 11(2), 107-127.

Note

Note 1 . The views and opinions expressed in this article are those of the authors and do not reflect those of the authors' employers.

\section{Copyrights}

Copyright for this article is retained by the author(s), with first publication rights granted to the journal.

This is an open-access article distributed under the terms and conditions of the Creative Commons Attribution license (http://creativecommons.org/licenses/by/3.0/). 